\title{
Financing Small and Medium Enterprise: A case study of BASIC Bank Ltd
}

\author{
Mihir Kumar Roy \\ Department of Business Administration, City University, Dhaka
}

Munira Muatarin

BASIC Band Ltd., Mirpur Branch, Dhaka

\begin{abstract}
The study was undertaken with the objective of analyzing the present Status of SME finance by BASIC Bank Ltd, Uttara Branch, and Dhaka. The data for the study were collected both from primary as well as secondary sources. The study revealed that the concerned branch provided working capital of Tk.18.5. crore in the SME sector during the study period with 13 percent interest rates which 77 percent of total loan portfolio was although purchasing fixed assets \& others constituted only 23 percent of the same. Majority of the clients belonged to the age between 30 to 50 years \& only 20 percent belonged to the age group of above 50 years. The profile of an enterprise as well as entrepreneur was studied as a test case for the study which generated sensation among the researchers. The study ended with some policy prescription which included more promotional activities of product \& services, arranging training for both loanees \& officers, analyzed customer's behavior specially repayment etc.The study concluded that by increasing the branches, BASIC Bank could expand their SME service throughout the country.
\end{abstract}

Key Words. : Small, Medium, Enterprises, Bank, Bagladesh

\section{Introduction}

\section{Background of the study}

Small and Medium Enterprises play an important role in the value addition of the economy and there by helps in the economic development of the country. It provides employment of millions of men and women, sources of technological innovations and new product make easy entry as well as exit of SMEs make economics more flexible and competitive and also work as subcontractors of the large companies. It also creates value addition to local price and can establishing forward and backward linkages. Besides, they can produce exportable surplus and thereby helps to earn foreign exchange.

Bangladesh is mainly an agro-based country and her economy has undergone rapid structural transformation towards manufacturing and services. SMEs have been considered as the principal driving force of Bangladesh's economy SMEs in Bangladesh, along with stimulating private ownership and entrepreneurial skills, are flexible and can adapt quickly to changing market demand supply, generate employment, help diversify economic activity and make significant contribution to the exports and trade of the country. The contribution of the agricultural sector to GDP has declined from 50 percent in 199973 to around 20 percent in 1999-2000 and 15 percent in 2008-2009 (BER, 2009). So, now boosting the SME sector the thrust sector of the economy should be an imperative. Along with growth of industrial sector which include large industry as well as SMEs, the micro finance sector in also contributing to the GDP silently by playing a significant role in the rural economy. The member- based MFIs constitute a rapid growing segment of Rural Financial market in Bangladesh. To provide financial service to the people, Grameen Bank (GB) and other nearly 1000 MFls are operating mostly in the rural sector of the country. These institutions have an explicit social agenda to cater to the needs of the poorer sections of the population and have a focus towards women clients. 
In the industrial sector, the SMEs are widely believed to the potential engine of economic growth of Bangladesh. According to the 2003 National Private Sector survey of enterprises of Bangladesh, the SME sector accounts for around $40 \%$ of the gross manufacturing outputs, $80 \%$ of the industrial employment and $25 \%$ of the total labour force in the economy. Although SME foundation and IFC- SEDF's efforts to create awareness among the banks and NonBanking financial. Institution to be more focused and SME in Bangladesh, the sector still needs greater support from both financial institutions and the government.

In a recent source, it is observed that there are 4-5 lacks SME in Bangladesh. According BER 2009, around $6 \%$ of the countries a total of US\$90 billion economy comes from SME and it is the largest sector in terms of employment generation and almost $30 \%$ of Bangladesh's economy is believed to be SME driven. The financing of Small \& Medium Enterprises (SMEs) has attracted much attention in recent years(de la Torre et al, 2010,P 2280). This is attributed to a number of reasons: (1) SMEs represent the majority of firms in an economy (de la Torre et al,2010)SMEs, (2) SMEs are important customers that offer the greatest profit opportunity for bank (Zineldin, 1995), and (3)most large companies start as small businesses(de la Torre et al, 2010) It therefore follows that banks should invest in building and enhancing the relationship with their SME customers. Such relational efforts would be largely driven by the acknowledgement of the benefits that accrue from relationship building; benefits which are all documented in the literature (Wilson,, 1995; Christopher et al, 2002).Even more so , banking is considered conducive to relationship development (Lovelock et al, 1999) and relationship banking can yield considerable benefits for both the financial institution and the SME. It should therefore not be surprising thjat banks perceive SMEs as a core and strategic business and seem well positioned to expand their involvement with them (de la Torre et al ,2010).
In particular, financial institutions can reach a competitive advantage through relationship development since relationship ease the collection of customer information. This is specially important since reliable information on SMEs is both rear and costly for banks, and as such relationship banking is often considered as the appropriate lending technique (Baas and Schrooten, 2005).This can in turn lead, on the one hand, to improved customer understanding and loyalty building and on the other, holding a strong fort folio of SMEs can help in achieving scale and scope economies, ultimately enhancing long term profitability (Reichhed Sasser, 1990). Similarly, relationships are desirable for the SMEs since they are more financially constrained than large firms (Schiffer and weder, 2001; IAD, 2004; Beck et al , 2005,2006$)$ and a positive relationship with their financial institution can reduce perceived risk \& uncertainty (Sheth \& Parvartiyar, 1995) \& provide greater assurance that funding will be available when needed ( Holland,1994).

Nevertheless, it appears that in practice, SMEs are given marginal importance: as Vegholm and Silver (2008) \& Silver \& Vegholm (2009) argue there is little evidence that banks adopt to the needs of the SME customers. This is also clearly evident from the banks' reaction to the financial crisis, whereby, instead of increasing attention on SMEs as a means of coping with with the crisis, many banks wanted to keep corporate customers \& get rid of the subprime portfolio and / or looked for capital injection, bailouts or restructuring or even sold part of their units

In such a situation, the banking industry has increased focus on financing to exhibit poor performance in SME credit disbursement despite the central bank's continuous efforts to boost it. In facts the average SME loan portfolio of PCBs is $13.45 \%$.In considering the above context, the issue of financing in SME is getting due importance by the central bank of the country. The Bank of the Small Industries and Commerce Bank Ltd (BASIC) registered under the companies Act 1913 on the $2^{\text {nd }}$ August 1988 started its operation from the $21^{\text {st }}$ of January 1989. It is governed 
by Banking Companies Act 1991.The main mandate of BASIC Bank Limited is to provide financial services to the small enterprises spread throughout the country. The proposed study on "Financing Small and Medium Enterprises: A case of BASIC Bank Limited, Uttara Branch" is a modest attempt by the researchers . It is the hoped the study will help bank management to handle their financing program more efficiently. The future researchers in this line will find a new way of their thinking specially the financial aspects and add to knowledge in the existing reservoir.

\section{Objectives of the study}

The broad objective of the study was to analyses the financial aspects of SMEs of BASIC Bank Limited, Uttara Branch, and Dhaka.

In specific term, the objectives of the study were as follows:

- To know the genesis and present status of SME finance in Uttara Branch, BASIC Bank Ltd.

- To analyses a case history of a small business enterprises financed by the branch.

- To explore the problem of SME financing.

- To suggest policy implication arising out of the study.

\section{Scope of the study}

The study was based on a case study of on SME financing. The entrepreneur of the KONA Fashion was interviewed to find out his ongoing process of implementing a SME enterprise under the financial support of BASIC Bank Ltd, Uttara Branch.

\section{Methodology}

\section{Data sources}

The data were obtained basically from two sources-

- Secondary Sources.

- Primary Sources.

\section{Secondary sources}

- Operation manuals of the bank.

- Annual Report of BASIC Bank Ltd.

- Policy manual of Small and Medium Enterprise financing of BASIC Bank Ltd.

- Periodical published by Bangladesh Bank.

- Uttara Branch, BASIC Bank total Portfolio which is divided by SSI and SMI.

- Various manuscripts, articles, assemblies.

- Website information.

\section{Primary sources}

The study was based on case study method and the methods of investigation employed in this study are given below:

\section{Study area}

Basic Bank Limited (Uttara Branch) 67/A (1 ${ }^{\text {st }}$ Floor) Rabindra Sarani, Sector-7, Uttara Model Town, Uttara, Dhaka-1230 was the study area of this research.

\section{Study sample}

As a case study, a single unit of small enterprise as well as twenty clients of the branch was selected purposely for the study.

\section{Sampling Unit}

KONA Fashion was selected as a sampling unit for the case study because the entrepreneur is one of the SME loans holders, provided by BASIC Bank, Uttara, Branch.

\section{Sample Size}

The size of the sample was limited to only one unit of small enterprise and twenty clients. In spite of that much concentration was given to make it as objectives as possible. It is hoped that this will fulfill the requirement of efficiency, reliability and flexibility. 


\section{Methods of data collection}

Mini questionnaire, personal interview, focused group discussions etc were employed to collect data for the case study.

\section{Data processing Method}

Data were processed through Ms Word, Ms Excel.

\section{Financing Small and Medium Enterprises (SMEs) in BASIC Bank Limited, Uttara Branch}

The very word entrepreneurship conjures up the thought of a developing society. Along with other areas that are necessary for an economy to get the thrust, entrepreneurship has been chalked out as a factor that combines the elements of completion, betterment of living standards and a motivation to stay on with the ideas of the rest of the world.

Entrepreneurship is the dynamic process of creating incremental wealth by individuals/groups through the use of resources. The individual or groups who perform these activities are called entrepreneurs. The entrepreneurial activities create incremental wealth which is a precondition to economic growth. The existence of entrepreneurs and its accelerated growth is a precondition to continuous and sustainable economic growth.

A small business is a business that is independently owned and operated, with a small number of employees and relatively low volume of sales. A small business can be started at a very low cost and even on part -time basis. Small business owners tend to be associate with their customers and clients very closely which results in greater accountability and responsiveness. However BASIC Bank would recognize and accept only those as enterprise which have valid trade license/ registration from competent authority and unquestionable business background.

Bangladesh Bank in its several circulars has instructed all banks / financial institutions to put their maximum effort on SME and also chalk out some Small Enterprise related guidelines for all. They have also instructed all banks and financial institutions to set their respective Small Enterprise Finance policy in line with the guideline provided. The policy guidelines have been established to shape and define the acceptable risk profile of BASIC Bank Ltd and to provide guidance in responding business opportunities as they arise.

Bangladesh bank in its ACSPD circular \# 8 dated 26.05.2008 declared unified definition for different size of enterprise. BASIC Bank will follow such definition, its amendment if any for financing small enterprise.

\section{Definition of small enterprise}

- A service concern with total assets at cost excluding land and building from TK: 50,000 to TK: 50 lac and total manpower not more than 25 .

- A trading concern with total assets at cost excluding land and building from TK: 50,000 to TK: 50 lac and total manpower not more than 25 .

- A manufacturing concern with total assets at cost excluding land and building from TK: 50,000 to TK: 1.50 lac and total manpower not more than 50 .

\section{Definition of medium enterprise}

- A service concern with total assets at cost excluding land and building from TK: 50 lac to TK: 10 crore and total manpower not more than 50 .

- A trading concern with total assets at cost excluding land and building from TK: 50 lac to TK: 10 crore and total manpower not more than 50 .

- A manufacturing concern with total assets at cost excluding land and building from TK: 1.50 crore to TK: 20 crore and total manpower not more than 150 . 


\section{Customer eligibility to apply for SME Loan}

Credit, whether secured or unsecured, must not be made available to a customer whether is a lack an understanding of the customer or the customer or the customer's business. The Bank will not extend credit products/ facilities which are inappropriate to the nature and scale of the customer's business. The customer should:

- Have the age of 18 years or above.

- Must be a national of Bangladesh.

- Must have business aptitude and an account with valid trade license.

- Understand the facilities and the associated risks.

- Have the authority to enter into the facility.

- The facility should be suitable for the customer needs.

- The facility should not be speculative.

- The size and structure of facilities is such that upstreaming or down-streaming of funds to the owners or associate companies are not facilitated.

\section{Borrower verification and selection of the clients}

- Before giving the SME loan BASIC Bank for fulfilling requirements of Know Your Customer (KYC) to Verify of the individual or corporate entity.

- Identification of the individual or corporate entity must be formally established through legal documentation.

- The borrower must be legally capable of entering a contractual credit relationship and providing a charge over any asset in any from taken as security for a loan.

- BASIC Bank must focus and priority that sectors of Small enterprises which are supposed to create employment opportunities and contribution to economic and social uplift as a whole.

- The owner must have entrepreneurship quality.

- The owner must be of integrity.

\section{Various products related to the SME finance}

BASIC Bank Limited, Uttara Branch is now involved in financing in various products as per their Credit Policy and Procedural Guideline.

Term Loan (Industrial Fixed Asset -Long \& Midterm)

Capitalized Expenditure (Long \&Mid Term)

Converted (Long \& Mid Term)

Short/Mid Term Loan (Work Order)

Short Term Loan (Import)

Short Term Ioan (Procurement of Merchandise)

Short/Mid Term Loan(Micro Credit)

Short/Mid Term Loan (Purchase of Office Appliances/Office renovation)

Short/Mid Term Loan (Financial Obligation)

Short Term Loan (Delivery Order)

Short Term Loan (Converted)

Cash Credit (CC) Hypo

CC Pledge

Export Cash Credit(Hypothecation)

Export Cash Credit (pledge)

SOD (Industrial)

SOD (Contractors \&Suppliers)

SOD (CDR)

SOD (Cheques \& Pay Order)

Loan against Import Merchandise(LIM)

Loan against Trust Receipt (LTR) 
Packing Credit (PC)

Payment against Documents (PAD)

Forced LIM

Forced Loan (Acceptance)

Forced Loan (Other Guarantees)

Loan against Documentary Bills (Local)

Loan against Documentary Bills (Foreign)

Letter of Credit $(\mathrm{L} / \mathrm{C})$

Acceptance

Bank Guarantee

Bills Purchase and Discount

\section{Area of Financing of Basic Bank, Uttara Branch}

BASIC Bank Ltd, Uttara Branch prioritizes various sectors for financing. The management of the bank from time to time ascertains projection on facilities toward various sectors as well as demand from the existing clients of the Bank. The sectors are given below:

1. Finance on small Food \& Allied manufacturing and trading.

2. Finance on small Printing, Publication \& Packaging Industry.

3. Finance on small Engineering, Electrical \& Electronics Industry.

4. Various Service Industries (small scale)

5. Small Handloom Industry

6. Silkworm and Silk Industry.

7. Tourism Industry.

8. Local Readymade Garment Traders.

9. Boutique Shop.
10. Photo Lab \& Studio.

11. Handicrafts

12. Grocery Shop.

13. Fast Food.

14. Electronic (i.e. T.V, Fridge etc) Repairing shop.

15. Departmental Shop.

16. Poultry \& Fisheries.

17. Pottery.

18. Any type of Coaching Centre or Training Institute.

19. Nursery.

20. Beauty Parlor.

21. Small Scale Furniture Factory.

22. Cosmetics and toiletries manufacturer $\&$ trader.

23. Computer software and related Goods trading (shop)

24. Artificial Flower Production \& Trading.

\section{Various units and organs for small enterprise} finance

Broadly, the bank will provides credit to its clients through following windows:

$>$ Small and Medium Enterprise Finance (i.e. SME Finance) unit.

$>$ Dedicated Women Desk.

$>$ Other agencies like NGOs, NBFI etc.

SME Service centre.

SME Unit: Establishment of SE cell / Dedicated Desk is an essential requirements per Bangladesh Bank guidelines. Hence, SE Cell / Dedicated Desk have to be established at Head office as well as in all branches of BASIC Bank.

SME Service Center: Not started yet. 
NGOs and other agencies for SME purpose: Not necessary that the whole SME would be financed by the bank. NGOs and other agencies are involves in this regard they are work in favor of the bank.

Women Entrepreneurs: The management of the BASIC Bank will introduce different loans schemes with different brand names for women entrepreneurs in order tom encourage and develop women participation in business. The management will take steps necessary for proper publicity of the schemes. Women entrepreneurs can easily apply for loan through branches.

\section{Approval Authority and Procedure of SME Loan of the Basic Bank}

Approval authority of all SME loans rests on the Board of Directors and the Managing Director. But considering the time factor for sanction of loans and to ensure proper and orderly conduct of credit business of the Bank the authority to sanction/ approval loans may be delegated to senior executives of the bank by the Board/Managing Director up to certain amount under certain terms and conditions.

Table: 1 : Approval Authorities by Different Tiers of Management

\begin{tabular}{|c|l|c|c|}
\hline SL. & \multicolumn{1}{|c|}{ Designation } & $\begin{array}{c}\text { With Collateral } \\
\text { (in lac TK.) }\end{array}$ & $\begin{array}{c}\text { Without } \\
\text { Collateral } \\
\text { (in lac TK.) }\end{array}$ \\
\hline 1 & Board of Director & 30 and above & 30 and above \\
\hline 2 & Managing Director & $* 30$ & - \\
\hline 3 & Deputy Managing Director & $* 20$ & - \\
\hline 4 & General Manager & $* 5$ & - \\
\hline
\end{tabular}

Source: SME Manual of BASIC Bank

All loans sanctioned shall comply with the requirements of Bank's Memorandum and Articles of Association, Banking Companies Act 1991 as amended from time to time, Bangladesh Bank's instructions and any other rules and regulations applicable.
All approvals must be evidenced in writing under signature of the approving authority. Records of approval shall have to be file with the Credit Application at the respective desks and SE Finance Unit and reported to the management on periodical basis.

\section{Amount of Loan Provide by the Basic Bank, Uttara branch}

Table 2 : Showing SME loans provide by BASIC Bank, Uttara Branch:

Working Capital (Tk)

\begin{tabular}{|c|c|}
\hline SSI & 102012594 \\
\hline MSI & 78916139 \\
\hline Total & 180928733 \\
\hline
\end{tabular}


Purchasing Fixed Assets \& Others

\begin{tabular}{|l|c|c|}
\hline Sector of Loan Area & Amount & Interest Rate \\
\hline Small Scale Industries (SSI) & TK. 51551108 & $12.50 \%$ \\
\hline Medium Scale Industries (MSI) & TK. 36006673 & $\mathbf{1 3 . 0 0 \%}$ \\
\hline
\end{tabular}

Source: Monthly Progress Report on 31.03.2010 of BASIC Bank Limited, Uttara Branch

\section{Different categories of business}

In studies of survey analysis, it was found that $55 \%$ of the clients are involved on trading business on the basis of banks enterprise scenario. Almost 30\% sample clients are carrying out manufacturing business in our country and few are engaged in service business

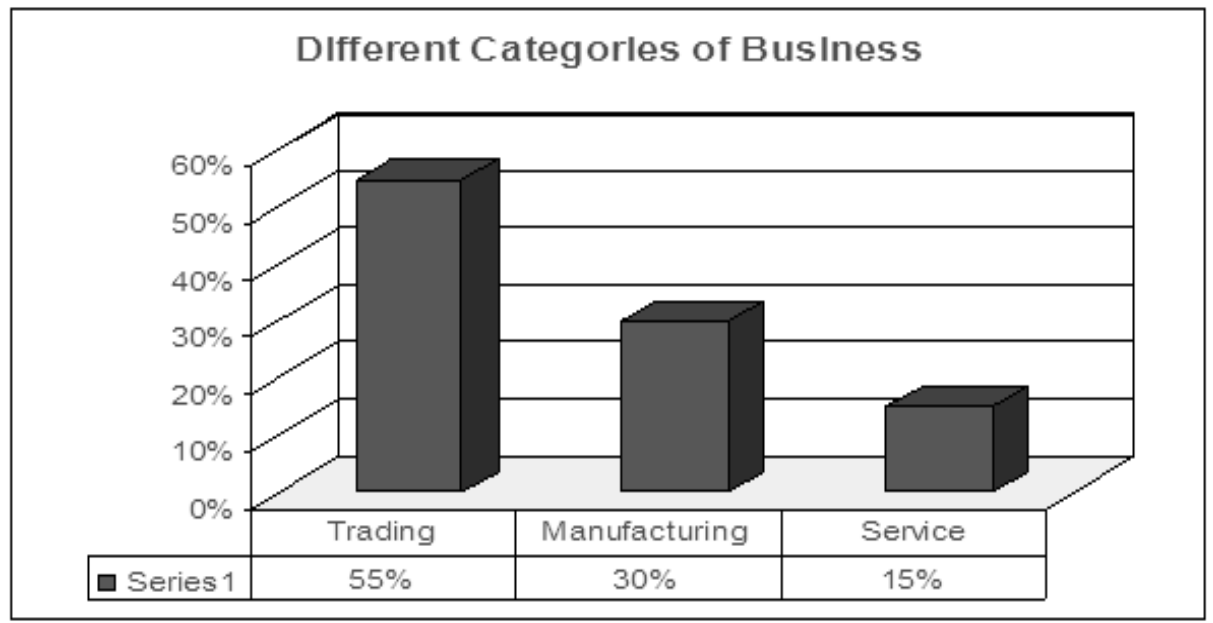

\section{Age Limit of the Client}

Figure 1

According to the survey, most of the clients are carrying out business whose ages are among 30 to 50 . It has been found that few clients are on above 50. SME believes that in studies of our age limit in this country it will be very risky to provide loans above 60 aged clients.

\section{Age of Clients}

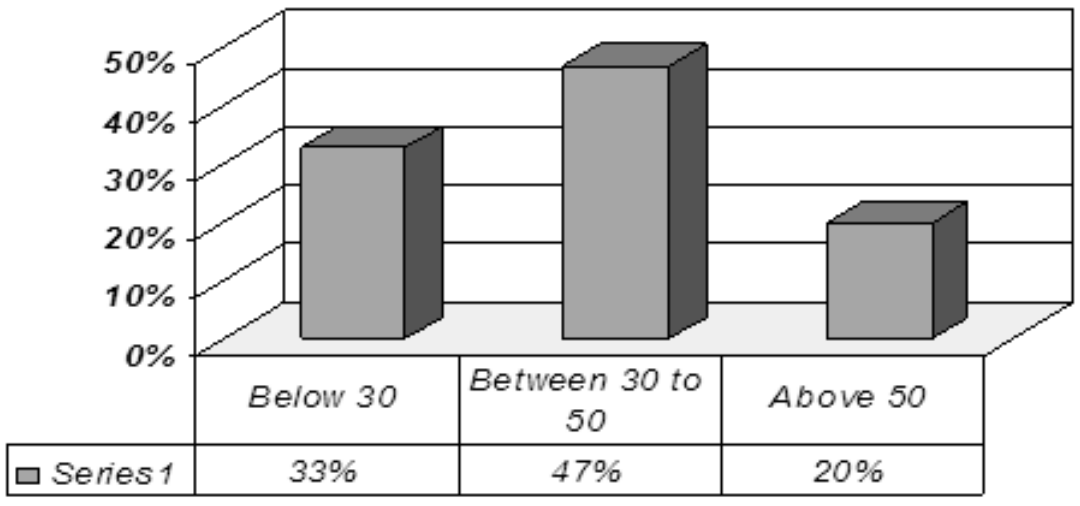

Figure 2 


\section{Business required any loans}

78\% clients demand small loans whether it can develop their own business, which found in the survey. Few clients think that to take loan might be risky to carry out the business.

\section{Business Required Loan}

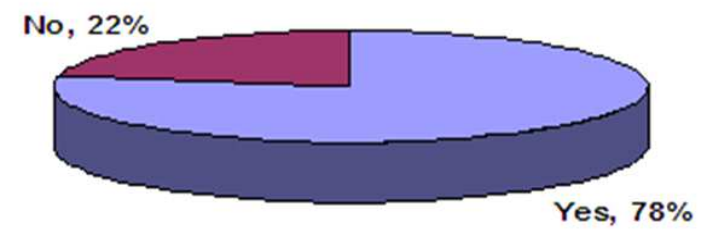

Figure 3

\section{Purpose of Loans}

According to the survey, it can analyze that most clients want loan to meet their working capital requirements. In our country most clients carry out trading business rather than manufacturing business. Few clients demand manufacturing loans to purchase of fixed assets. In this case clients require medium loans like 15-30 lacs for purchasing fixed assets.

\section{Purpose of Loan}

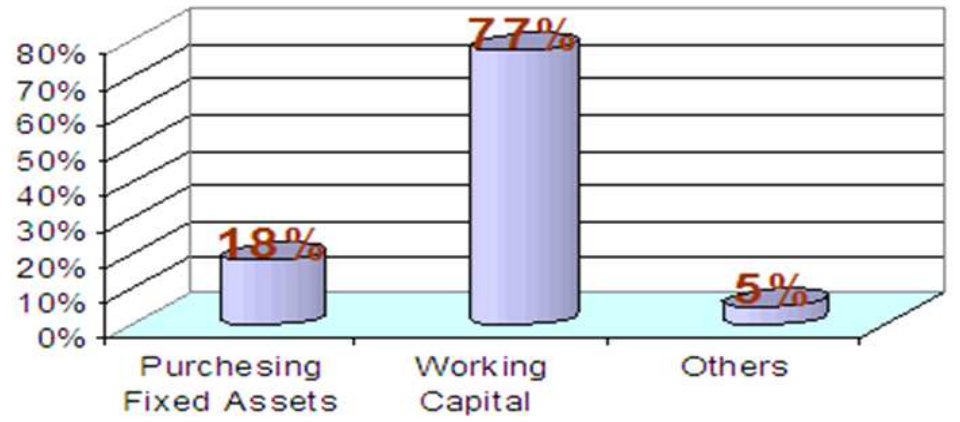

Figure 4

\section{Rate of Interest}

$52 \%$ clients are satisfied on existing interest rate by comparing with other banks. Most clients prefer reducing balance method that BASIC Bank proportion in favor of clients. $43 \%$ clients are not happy to get this loan with charged interest rate. They think interest rate should be reduced. $5 \%$ clients disagreed to comment on this regard. SME believe that they do not have any hidden costs and free from bribes. It is a fresh organization whether clients can have for loans. 


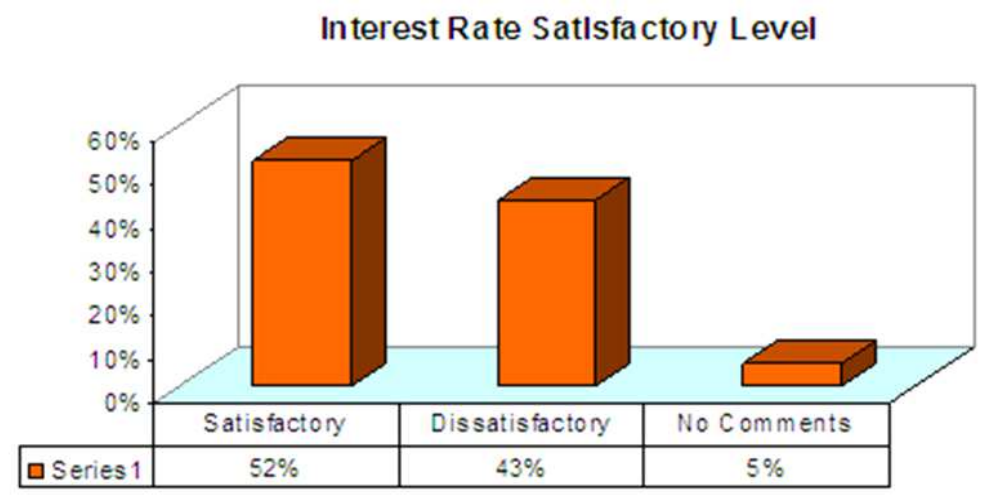

Figure 5

\section{Duration of Loans}

In spite of analysis, most clients want more duration or time to repay the SME loan. More time means less amount of money to repay the loan whether clients think beneficial of it. Very few clients demand short study or single payment loan to repay.

\section{Security Preference}

According to the survey, it can imply that $75 \%$ of the clients want to provide deposit hypothecation of business assets against loan which also they feel less risky. If the clients go for big amount then they have to deposit registered or equitable mortgage against loan which they feel too much risky. But land property sometimes carry triples amount of security from loan amount. So it they fail then they might sell their property.

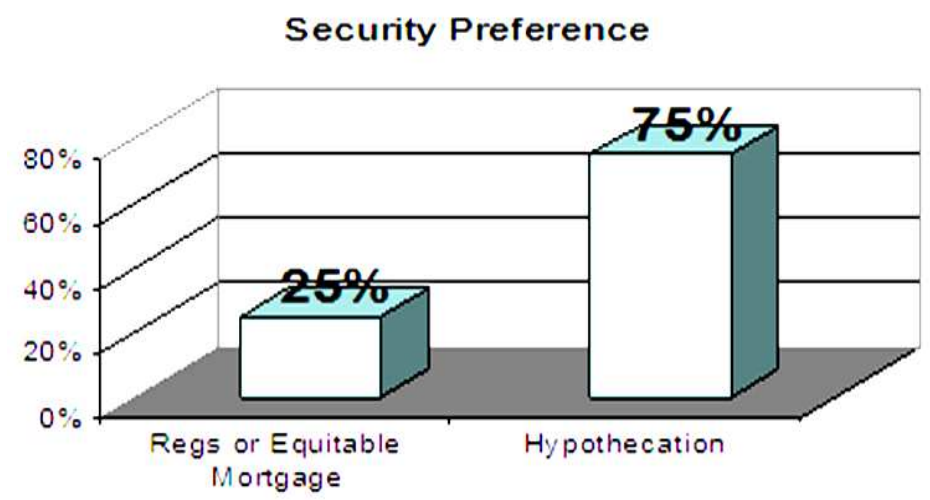

Figure: 6

\section{Clients want fast service}

According to the survey, it can be said that $55 \%$ of the clients avail the loan within 15 days. In studies of getting the loan clients buy the raw materials or order suppliers. A good number of sample clients will be satisfied if they get loan with 20-23 days. They are general clients and they do not have hurry to carry out business. Very few clients opine more than 25 days because in this case clients deposits land security. So automatically it takes more time to avail the loan. 
Time Requirement for Loan

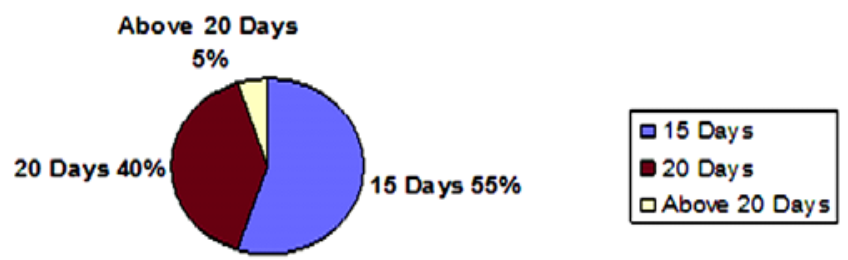

\section{Repay Monthly Installment}

Figure 7

Majorities of clients are happy to repay the loan by equal monthly installment. Clients know when where and how they will repay the money. So there is not botheration between clients and CRO.

\section{Client Repay Monthly Installment}

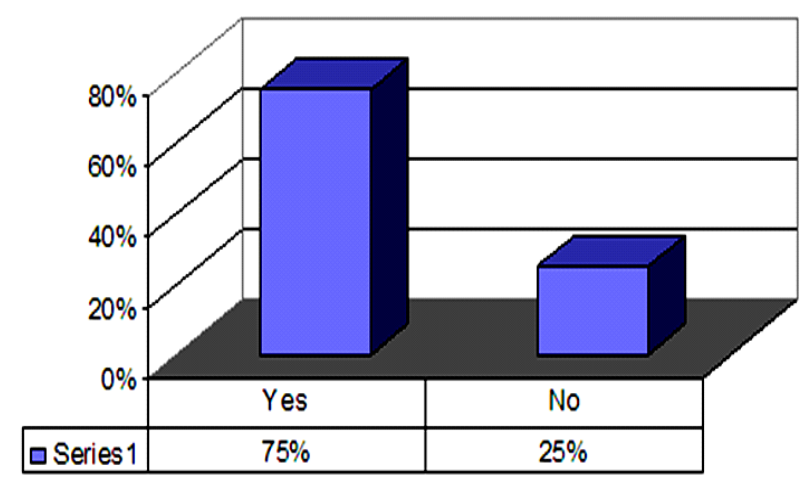

Figure 8

\section{Business Expansion from Trading to Manufacturing}

In studies of survey, it has found that almost $55 \%$ of clients interested to expand the business from trading to manufacturing. Purpose of the loan is economic development in our country, which might divert the clients mind after having the loan expansion. 30 clients are not interested to expand their business from trading to manufacturing. $15 \%$ did not answer this question.

\section{Business Expansion From Trading to Manufacturing}

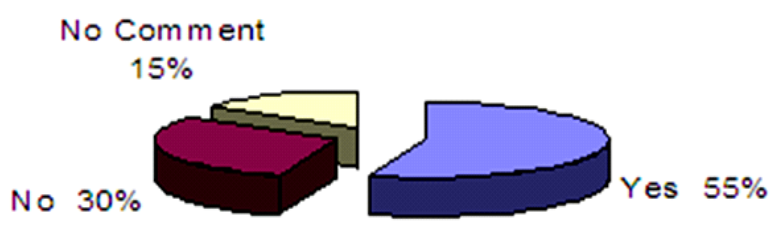

$$
\text { पYes } \square \text { No } \square \text { No Comment }
$$

Figure 9 


\section{Profile of the Entrepreneur and Enterprise}

Every SME client of BASIC Bank Ltd, Uttara Branch had to fulfill a certain criteria before getting the approval of enjoying their SME facilities. Mr. Md. Kamrul Islam also had to fulfill those criteria before getting his loan. The following are a snapshot of his personal and professional profile:

\begin{tabular}{|c|c|}
\hline Name of Entrepreneur & Mr. Md. Kamrul Islam \\
\hline Father's Name & Md. Abdul Kuddus \\
\hline Mother's Name & Sufia Begum \\
\hline Present Address & Arichapur, Tongi, Gagipur \\
\hline Permanent Address & $\begin{array}{l}\text { Village: Raghunathpur,P .S.Kendua, } \\
\text { Dis.Netrokona }\end{array}$ \\
\hline Name of Business Organization & $\begin{array}{l}\text { M/S KONA FashionHouse\# 43, } \\
\text { Road\# 18, Sector \#3, Uttara, Dhaka }\end{array}$ \\
\hline Type of Business & Block Print, Embroidery and Tailoring \\
\hline Date of Established & 25.11.2004 \\
\hline Constitution & Proprietorship \\
\hline Accounting Opening Date & 11.09.2006 \\
\hline Introduce by & $\begin{array}{l}\text { Md. Mokhlesur Rahman } \\
\text { Prop. Siam Offset Press }\end{array}$ \\
\hline Starting Capital & $5 \mathrm{lac}$ \\
\hline Present Capital & $108.55 \mathrm{lac}$ \\
\hline
\end{tabular}

Source: BASIC Bank, Uttara, Branch

\section{The motivational forces behind the success}

Mr. Kamrul Islam brought up lower middle class family where all family members were fight to the poverty. His father Mr. Abdul Kuddus was a farmer. His father was always being in extreme exhaustion for fulfilled of his family's basis needs. That time Mr. kamrul Islam and and his family were stay in the Netrokona. Mr. kamrul Islam was a elder brother among five brother and sister. So automatically he had a lot of responsibility from childhood period. He always saw his father and mother were tolerating lots of privation. Kamrul Islam was always thought he must do something for his family. In that situation it was difficult to continue of his study. For helped his family and continued his study he was teaching to the village school students, that time he was only 15 years old. Then after a long hardship Mr. Kamrul Islam passed S.S.C in 1990 and H.S.C in 1993. He was thinking about his family father, mother his sisters and little brother also their previous privation situation. All practical through was work as a real motivation for him to do great things in life. The whole negative situation 
changed into a positive force and it was his fortitude and self-esteem that he accepted the challenge thrown to him from time with a smile.

\section{The struggles towards success}

Once upon a time he felt he should do something new which is much better and given more money to his family. Then in middle of the 1993 he came to the Dhaka. In Dhaka he was get in to his so called village relative uncle's house. His uncle's name was Mr. Rahman. He had a Sawmill and a shop of the wood. He proposed to Kamrul Islam for in his shop. Kamrul Islam was instantly agreed in his proposal. But that time was not talked about Kamul Islam's salary. Kamrul Islam also decided he continued his study because nothing is possible without study. For this reason he was admitted in Titumir College in B.A. So he continued both in same time. He was always done hardworking. After one month when he was get salary he felt he was happiest person in the world. Whatever he was get a little amount money only TK. 2000. In this amount of money Tk.1000 he was sends to Netrokona for his family. He felt he needs lots of money for maintaining his family properly. In this reason after closing the shop he was teaches students. He tried to deposit some money from his salary and his tuition's salary. He always did hardworking because one side must send money for his family and other side he deposited money for future. One day he heard about share business in Dhaka Stock Exchange, where possible to earn huge amount of profit. In early 1995 he decided he will buy share from share market. For this reason he borrows TK.50000 from his friend and also his deposited money both are invested in share market. He brought two companies shares. That time he always thought how he could free off his debt. After three months his share rate was up and he was sells his share. In his first business he was gainer and he earned profitTk.50000 that means he earned TK.120000. Firstly he paid off his friend's loan then he decided he brought much share from previous time. That time he also continued his job and teaching. One day he felt so lonely and missed his family. He decided he bring his family from Netrokona to Dhaka. He discussed with his boss or so called relative. His boss said, "It is so expensive to live in Dhaka City and also difficult to bear expense for you. Because here house rent is high. If you have a land or house then you can bring your parents." After that conversation he decided he buy a land if he earn profit his current share. After six months he was sell his share and that time he also earned profit. He earned total TK.200000. Then he talked his boss and other people for buy a land within a cheapest rate. One day one of the client of his work place that person said to Kamrul Islam he find out a land which was situated Chanpare, DistGagipur, 8.25 decimel land and little bit inside of the main road. Kamrul Islam visited and brought the land TK. 150000. The rest of TK. 50000 he was investing in share market. In 1996 when share market indicator was fall and time huge amount of Share price was fall. Kamrul Islam loss TK. 50000 and that time he was impoverished and passed a difficult time. Mr. Kamrul Islam was in total distress at that time and didn't know what step he should take. Should he set out to catch his dream? But he didn't get back. He continued his job. After a few months Mr. Kamrul Islam decided to take a short leave from his job to go to his village. 
He was quite happy while he was returning home. It was such a long time that he didn't see his mother and little sisters. He couldn't wait any further to meet them, hug them and talk to them. Finally he reached his village. It was one of the most beautiful and emotional moments in his life. He could see the unselfish love in his mother's and sisters' eye flowing in the form of tears. After a few days he came back to Dhaka before came his father said they need more money for his sisters and brother's study. All journey time he was only think which is the way of earn more money. After a few days he was borrow TK.100000 from his boss and also mortgage his land paper to his boss. In that money he rented a shop in Tongi market and he decided he started business. He was bring shares from Islampur after a few months his shop was most popular in Tongi for varieties share and one year later he paid off his previous boss loan and get back his land paper. Then he decided he was bringing his family from Netrokona.

\section{The beginning of his business}

One day when he went to the Islampur by bus he heard two young men talked about a new business. They said today's women are more fashionable he wants to try new dresses like block, tidry, spray printing, embroidery so this types more profitable and less investment. Mr. Kamrul Islam was interested about their topic and he asks them detailed about the business. They said it is a profitable business but must needed struggles and hardworking. He was also know after starting the business must need training on this business subject and Bangladesh ЈОво UNNOON are provide training to the all young people. They talked each other until he was not reached. MR. Kamrul Islam took their address because this type was really a new business for him. One day he went to the Jobo Unnoon and admitted for 6 months training on Block, Spray printing, Embroidery. After a successful training he got a TK. 100000 loan from his training center without mortgage anything. Then he closed his previous business and sells all things there from got TK.200000 and also sells their Netrokona's land which was from get TK. 200000. Total TK.500000 he started his business. Firstly he rented a shop which was House\# 43, Road\# 18, Sector\# 03, Uttara, Dhaka monthly rent was TK. 50000. Then he started his business 2004 November. Name of his shop was KONA FASHION. Firstly he started with 5 workers in his shop. Day by day his shop was most popular in Uttara and Tongi and he got lots of order. Mr. Kamrul Islam mainly engaged in Tailoring, Block and Embroidery business like Shree, Three pieces, Bed Sheet, Pant, Shirt, and Fotua etc.

\section{Introduction with Basic Bank's SME Loan}

Mr. Kamrul Islam decided he expend But he was being extreme exhaustion to delivery all order for deficiency of money. One day he talked with Md. Mokhlesur Rahman about his problem he is owner of Siam Offset Press which is nearest shop of the Kona Fashion. In that time Md. Mokhlesur Rahman said him about the BASIC Bank's SME loan. Which maily created for helping the entrepreneur? Mr. Kamrul Islam had absolutely no idea about the matter and he thought if he wants to know about the matter he should personally visit the bank which is providing the scheme. He took the suggestion seriously and visited BASIC Bank and firstly he opened his own account and then spoke about the offer which they are providing (SME Loan). Bank's officer told him which paper will be submitted for loan and which types of requirement are should be fulfill. Then he applies for loan with an application. Then in 2007 March sanction his first SME loan. 
Amount of SME Loan

Table 3 : Amount of SME loan

\begin{tabular}{|c|c|c|c|c|c|c|}
\hline Particulars & $\begin{array}{c}\text { Date of } \\
\text { sanction/ } \\
\text { renew }\end{array}$ & $\begin{array}{l}\text { Sanctioned } \\
\text { Facility }\end{array}$ & $\begin{array}{l}\text { Sanctioned } \\
\text { amount }\end{array}$ & $\begin{array}{l}\text { Rate of } \\
\text { Interest }\end{array}$ & $\begin{array}{l}\text { Date of } \\
\text { Expiry }\end{array}$ & Remarks \\
\hline Sanction & 05.03 .2007 & $\mathrm{CC}(\mathrm{H})$ & TK.3.00 lac & $\begin{array}{l}13.00 \% \text { P.a. which } \\
\text { may be changed at } \\
\text { the discretion of } \\
\text { the bank. }\end{array}$ & 27.03.2007 & Paid \\
\hline Sanction & 19.05.2009 & $\mathrm{CC}(\mathrm{H})$ & TK.8.00 lac & $\begin{array}{l}13.00 \% \text { P.a. which } \\
\text { may be changed at } \\
\text { the discretion of } \\
\text { the bank. }\end{array}$ & 31.05.20.10 & $\begin{array}{l}\text { Ad-hoc } \\
\text { facility fully } \\
\text { adjusted }\end{array}$ \\
\hline Sanction & 28.07.2009 & Ad-hoc & TK.4.00 lac & $\begin{array}{l}13.00 \% \text { P.a. which } \\
\text { may be changed at } \\
\text { the discretion of } \\
\text { the bank. }\end{array}$ & 28.10.2009 & Paid \\
\hline Sanction & 11.03.2010 & STL & TK.3.00 lac & & 31.05.2010 & \\
\hline \multicolumn{2}{|c|}{ Security/Registered } & \multicolumn{5}{|c|}{$\begin{array}{l}\text { Primary: Hypothecation of stock - in trade of trading items duly insured } \\
\text { with bank clause. }\end{array}$} \\
\hline \multicolumn{2}{|c|}{ Total Value: Tk. 19.80 lac } & \multicolumn{5}{|c|}{$\begin{array}{l}\text { Secondary: } \\
\text { Hypothecation existing machineries and stock of raw materials and } \\
\text { finished goods like Sharee, Three pieces, Bed Sheet, Panjabi, Shirt, } \\
\text { Pant, Fotuya etc duly insured in favor of our bank, valuing TK. } 34.10 \text { lac. } \\
\text { (ii) Existing registered mortgage of } 8.25 \text { decimal vacant land demarcated } \\
\text { by pillar under Mouza- Chanpara, P.S-Gazipur, Dist-Gazipur demarked } \\
\text { by pillar valued at TK. } 9.90 \text { lac. } \\
8.25 \text { decimal vacant lands demarcated by pillar under Mouza- Chanpara, } \\
\text { P.S-Gazipur, Dist-Gazipur demarked by pillar valued at TK. } 9.90 \text { lac. }\end{array}$} \\
\hline
\end{tabular}

Source: BASIC Bank, Uttara Branch 


\section{Particulars of Proposed}

Table 4

\begin{tabular}{|l|l|}
\hline Facility & $\begin{array}{l}\text { Enhance of cash credit (Hypothecation) limit from } \\
\text { Tk.8.00 lac to Tk.20.00 lac. }\end{array}$ \\
\hline Purpose & To maintain sufficient stocks for smooth supply to the customs. \\
\hline Margin & $50 \%$ minimum on invoice value or smooth supply to the customers. \\
\hline Rate of Interest & $13.00 \%$ p.a. which may be changed at the discretion of the bank. \\
\hline Mode of Repayment / Adjustment & Daily sale proceeds to be deposited in the C.C.(H) A/c. \\
\hline
\end{tabular}

Source: BASIC Bank, Uttara Branch

Present Status

Table 5 : Present Business Statues

Starting investment TK. 5.00 lac

\begin{tabular}{|l|l|}
\hline Asset Worth & TK.108.55 lac \\
\hline Number of Shop /Factories & $\begin{array}{l}\text { One shop and Five boutiques and one screen print factories } \\
\text { all are situated in Uttara. }\end{array}$ \\
\hline Business Type & Tailoring, Block Print, Spray Print, Screen Print, Embroidery. \\
\hline Industry Type & It is a labour intensive industry. \\
\hline Target Market & Middle and upper class people. \\
\hline Business position/Coverage Area & Uttara, Tongi, Banani. \\
\hline Business process & Kona Fashion sell their products their own shop and also supply \\
or sell Uttara, Banani and Tongi's different types of boutique shop.
\end{tabular}

Source: Mr. Kamrul Islam

\section{Future plan}

The future plan of Mr. Kamrul Hasan about the "Kona Fashion" is very much organized. Firstly he wants to expand his business area all over the Dhaka City. Then he will open his own showroom in Jamuna Future Park Shopping Mall with a large size. Kona Fashion also get order of screen print from different types of garments, so Mr. Kamrul Islam will also wants to expand his garments customers. Only from Tk. 5.00 lac investment money today Mr. kamrul Islam total asset increased to TK.108.55 lac, so it is possible for hardworking for this reason Kamrul Islam also wants to continued his hardworking in future. 


\section{Problem of the entrepreneur regarding of the} bank

- Bank interest rate is high.

- Duration time of the pay off the loan is very short. So limited time is the very much burden for the entrepreneur.

- Loan amount is very low against securities.

- Without reputed introducer not possible to open the account and also not get the loan.

- Getting the loan is really extensive after applying the loan.

\section{Objectively analysis the entrepreneur's problem}

- After talking the bank manager about the Mr. Kamrul Islam Problems find out some reasons which are work behind the problems.

- BASIC Bank Limited is a $100 \%$ government owned bank. So it is strictly maintain some rules about all matters.

- BASIC Bank follow the Bangladesh Bank's SME policy manual which contains the core principles for identifying, measuring, approving and managing credit risk revolving around the small enterprise financed by the bank.

- As a government bank sanction of any kind of loan pass a lengthy process because when any loan proposal submitted in branch then branch send it to the Head office. Head office takes 7 days and then Head office process the proposal with due diligence and take decision by the Board of Directors meeting.

- Not possible to maintain the loan amount and the securities values. Because most of the time it's involve different types risk. Like, Mr. Kamrul Islam's bank security values against loan its most of the portion of his business's raw materials and machineries. So any type of mishap or accident creates a high risk for bank.
- It is not really that, the BASIC Bank loan interest rate is high. Because of comparatively other banks which are providing the SME loan their interest rate is high rather than BASIC Bank.

- For maintaining Bangladesh Bank rules and for safety BASIC Bank want to a reputed introducer because if any of reason client are not able to pay off the loan that time introducer bear the loan.

\section{Findings from the Case Study}

\section{Explain below some Entrepreneur characteristic which are found in Mr. Kamrul Islam}

> Confidence: MR. Kamrul Islam is a confidence person. He never acknowledges defeat to his poverty. For this reason from a poor farmer's son he makes him billionaires. He never compromises anything and he continued his study and also when he faced loss in business that time he handles everything with his confidence.

Independence: He had always independence mentality. For this reason he started teaching and sells man profession for helping his family and continued his study.

Honesty: Mr. Kamrul Islam always paid off his loan in on time its carry his honesty characteristic.

Energy and Diligence: Mr. Kamrul Islam is every energetic person. This made him a successful entrepreneur. From first to till he done hard working. He continued his study also continued his sells man profession and teaching to the students. Mr. Kamrul Islam started Kona Fashion only one shop but his diligence and energy possible to establish six factories and shop.

Risk Taking Capacity: One of the most important characteristic of entrepreneur is risk taking capacity. This is most related to the Mr. Kamrul Islam. In his whole life he was always taking different types of risk for gained his business. 
Intelligence: Mr. Kamrul Islam is very intelligent person. For this reason, very begging of his age he understood education has great value and it can make a successful life and early of the age he felt that to eliminated his poverty he was must be independent and done hard work.

\section{Whether Md. Kamrul Islam Comparable to a Successful Entrepreneur}

Mr. Kamrul is definitely comparable to a successful entrepreneur. He has all the qualities of an entrepreneur and is always optimistic to achieve good things. He is always looking forward to take up new challenges and is a good risk calculator. He has systematically arranged his business and driven it to a successful path with healthy profit. Mr. Kamrul Islam also has future plans and always has the hunger to succeed.

\section{The Implied Reasons behind Md. Kamrul Islam for Becoming a Successful Entrepreneur}

Mr. Kamrul was in a very difficult position. Maintaining the family is difficult for his father. For continued his study he passed an intricate time. At last he came to Dhaka for helping his family change their situation. At a very young age he took the decision to fight against his faith and succeeded. The untimely catastrophe with his family urged him to become an entrepreneur.

\section{The Lessons from Mr. Kamrul Islam And How It Can Influence a Man to be an Entrepreneur}

The story of Mr. Kamrul Islam, a Bangladeshi citizen, is a prime example of someone who has succeeded through determination, by asking for information and guidance and by making use of intellectual property. It shows also that cases of success are not confined to America or Europe alone, but that Bangladesh business or individual can just as well achieve success through development and help provided by various financial institutions. Mr. Kamrul Islam set an example not only for the people like him but for the whole nation that determination, hard work, willpower, risk taking mentality, self confidence, never acknowledge defeat mentality, achieve more money and self-control can lead anyone to achieve the impossible. The lesson which we learned from all his experience is; "Necessity is the father of all Inventions".

\section{Md. Kamrul Islam- An Opportunity Seeker With Examples.}

Mr. Kamrul Islam is an opportunity seeker and has always grabbed the opportunity to go ahead in life. He initially grabbed the opportunity and to fully trained up about his business from JOBO ONNON. Then after gaining sufficient experience made the full use of it by opening his own business and finally grabbing the opportunity provided by BASIC Bank Ltd. He made full utilization of the SME loan that brought him to this position today.

\section{What Made Mr. Kamrul Islam a Great Businessman?}

The determination, the dedication, the ability to motivate himself and others and the intelligence and integrity of Mr. Kamrul Islam has made him a great businessman. Even in the most difficult situations he has been able to find out the best solutions with good results to show for it.

\section{Policy Implication and Conclusion}

\section{Policy Implication}

Most of the people don't know BASIC Bank is a government owned Bank and also don't know about its SME loan. So BASIC Bank Limited needs more promotional activities of their products and service.

Start SME service center as soon as possible. The main aim of the SME service should be motivate the prospective entrepreneurs and finance them according to their requirement. 
* BASIC has no customer relationship officer. So it is necessary to recruit customer relationship officer and by providing training should be make them more comprehensively and realistically by that customers may not face any trouble while getting and repaying the loan.

* The Bank should work on that, which SME loan they are provided those loans have properly utilized and for the same propose for they were acquired.

* Analyze customers' behavior that what type of customer makes default and stop giving them SME loan.

* Risk Management department's audit report should be more strict and reliable so that possible defaulter may not get the loan.

* By arranging various workshop, seminar, Training program etc for the new entrepreneurs.

* Find out the potentiality of the business, understand the needs of the customers and cooperate the new entrepreneurs with their ideas, experience and thoughts.

\section{Conclusion}

This is a well-established statement that practical situations always differ from theoretical explanation As a government bank BASIC Bank is trying it's best to extend their service to the public. A very working environment was remaining in the BASIC Bank, Uttara Branch. During the study period, it was found that the Uttara Branch provided all kinds of commercial banking services to its customers. Foreign Exchange Department rendering all the services related to international trade and remittance. Loans and advances analyses credit proposal and disburse credit if proposal is sound .General banking is engaged in cash receipt and payment, cheque clearing, local remittance etc.The present SME dealing of BASIC Bank LTD is comparatively satisfied.\& by increasing their branches BASIC Bank can expend their SME service all over the country.

\section{References}

Annual Report(2009) BASIC Bank Limited, Head Office, Dhaka.

Baas, T and Schrooten , M,(2995)," Relationship Banking and SMEs: A Theoretical Analysis (January 2005)," DIW Discussion Paper No: 469," available at http:// ssrn.com/abstract==78834 (accessed 20 June 2009)

Christopher, M, Payne, A. and Ballantyne, D.(2002), Relationship Marketing: Creating Stakeholder value , Oxford, UK: Butterworth-Heinemann Ltd.

Small and Medium Enterprise Financing Policy Manual of Basic Bank Limited.(Published by Bangladesh Bank)

Several Booklets from Basic Bank, i.e. Basic Kolanni, Basic SME etc.

Operational Guidelines for Loan and Advances. (Published by BangladesBank)

Documents and other necessary papers of 'Kona Fashion' from BASIC Bank Ltd, Uttara Branch.

de la Torre, A, Martinez Peria, M.S., and Schmukler S (2009)," Bank Involvement With SMEs : Beyond Relationship Lending,' Journal of Finance \& Banking, 34, 2280-2293

Zineldin, M. and Jonsson, P.(2000)," An Examination of the Main Factors Affecting Trust / Commitment in Supplier- Dealer Relationship: Am Empirical Study of the Swedish Wood Industry," The TQ Magazine 12 (4), 245-265 


\section{Appendix : ACRONYMS}

\begin{tabular}{|c|l|}
\hline BASIC & Bangladesh Small Industries \& Commerce \\
\hline CC & Cash Credit \\
\hline CRO & Customer Relation Officer \\
\hline MSI & Medium Scale Industries \\
\hline SSI & Small-scale Industries \\
\hline SOD & Secured Overdraft \\
\hline TOD & Temporary Overdraft \\
\hline
\end{tabular}

\section{Authors' profile}

Dr. Mihir Kumar Roy is currently a Professor of Business Administration and Co-ordinator, Internship and Placement, at the City University, Dhaka. Earlier positions held by him include: Associate Instructor ( Farm Management) Rural Development Academy, Bogra (1976-81); Faculty Member in Agricultural Economics, Bangladesh Institute Of Bank Management (BIBM) Dhaka (1981-1996), and Director , Bangladesh Academy for Rural Development (BARD), Kotbari, Comilla from (1996-2008). His prominent publications include Studies in Rural Banking (1994 , 1998); Generation of Employment (1999), linkage between GOs and NGOs (20000); People's Participation in Forest Resource Management (2003); Moheshpur : A Village Study (2003); Process of
Graduation Among the Resource Poor Farm Househoids in a Bangladesh Village (2004); Comprehensive Village Development Programme (2004) Cross Cultural Community in Bangladesh (2005); Hill Agriculture (2006), Good Governance in Rural Development (2008) etc. are prominent. He has published more than three dozens of scientific articles in National and International journals

Munira Muatarin Liza is currently an Assistant Officer in Credit and Investment wing of BASIC Bank Ltd, a Govt. own bank, Mirpur Branch, Dhaka. She has a MBA fromSouth East University in 2012 and a BBA from City University in 2010 with Major in HRM. She has experience to work at R\&G Company \& a strong background in computer literacy. 